\title{
Equipment
}

\section{The output of four modern vaporizers in the presence of helium}

It has been previously demonstrated that the output of calibrated vaporizers is influenced by the concentration of nitrous oxide in the carrier gas. This study was performed to determine whether helium in the carrier gas affects the output of modern calibrated vaporizers. A factorial design was used to determine the influence of carrier-gas helium concentration, carrier-gas flow rate and vaporizer dial setting on the output of four vaporizers: Ohio Calibrated Enflurane, Ohio Calibrated Isoflurane, Ohmeda Isotec 4, and Dräger Vapor 19.1 Isoflurane. Three vaporizers of each model were tested. Output was converted to \% of baseline so that different dial settings could be compared. For a given dial setting, baseline was defined as the output at a carrier-gas flow rate of $3 \mathrm{~L} \cdot \mathrm{min}^{-1}$ and helium concentration of zero. The data were analyzed using multiple linear regression. There was an effect of helium concentration on vaporizer output in all models. None of these changes was clinically important, since vaporizer output did not vary by more than $\pm 10 \%$, except at high flows and at high helium concentrations with the Ohmeda Isotec 4. It is concluded that these vaporizers can be used safely with helium.

Il y a déjà été démontré que le débit des vaporisateurs calibrés est influencé par la concentration du $\mathrm{N}_{2} \mathrm{O}$ dans le gaz vecteur. Cette étude fut réalisée pour déterminer si l'hélium dans le gaz vecteur affecte le débit des vaporisateurs calibrés modernes. Un modele factoriel a été adopté pour déterminer l'influence

\section{Key words}

EQUIPMENT: vaporizers;

GASES, NONANAESTHETIC: helium.

From the Department of Anesthesiology, University of California, Davis Medical Center, Sacramento, California.

Address correspondence to: Dr. Robert G. Loeb, Department of Anesthesiology, University of California, Davis Medical Center, Sacramento, CA 95817.

Presented in part at the 1989 Annual Meeting of the American Society of Anesthesiologists.

Accepted for publication 1st June, 1992. de la concentration d'hélium dans le gaz vecteur, son débit et la graduation du vaporisateur, sur le débit de quatre vaporisateurs: Ohio calibré pour l'enflurane, Ohio calibré pour l'isolurane, Ohmeda Isotec 4 et Drager Vapor 19,1 pour l'isoflurane. Trois vaporisateurs de chaque modèle furent testés. Le débit fut converti en \% d'une valeur de base de telle sorte que les différents types de calibration puissent être comparés. Pour un degré d'ouverture déterminé, une valeur de base fut définie pour un débit du gaz vecteur de $3 \mathrm{~L} \cdot \mathrm{min}^{-1}$ en l'absence d'hélium. Les données ont été analysées par une régression linéaire multiple. La concentration d'hélium a eu un effet sur le débit des vaporisateurs de tous les modèles. Aucune de ces modifications n'a été cliniquement importante, car le débit des vaporisateurs n'a pas varié de plus de 10\%, sauf à hauts débits ainsi qu'à haute concentration d'hélium avec le vaporisateur Ohmeda Isotec 4. On conclut que ces vaporisateurs peuvent être utilisée sans danger avec l'hélium.

Anaesthetic vaporizers are designed to deliver anaesthetic concentrations which correspond to the dial setting. Ideally, vaporizer output should not vary with changes in temperature, carrier-gas flow rate, or carrier-gas composition. However, the output of vaporizers is considerably influenced by the concentration of nitrous oxide in the carrier gas. ${ }^{1}$ This effect has been attributed to nitrous oxide's high solubility in liquid anaesthetics and low viscosity. ${ }^{2}$ The low viscosity of nitrous oxide changes the flow profile through the vaporizer's flow divider.

Helium, a low density gas, has been recommended for general anaesthesia for endoscopic laser surgery ${ }^{3}$ and in patients with respiratory obstruction. ${ }^{4,5}$ Previous studies have concluded that some vaporizers are influenced by helium. ${ }^{1,6}$ This study was performed to determine whether helium in the carrier gas affects the output of four modern calibrated vaporizers.

\section{Methods}

A $4 \times 4 \times 4$ factorial design ${ }^{7}$ was used to evaluate the effect of helium concentration in the carrier gas, carriergas flow rate, and vaporizer dial setting on vapour output 
TABLE Result of multiple linear regression analysis of vaporizer output versus carrier-gas flow rate, helium concentration, and dial setting for four vaporizer types

\begin{tabular}{lllll}
\hline & $\begin{array}{l}\text { Ohio Calibrated } \\
\text { Isoflurane } \\
n=168\end{array}$ & $\begin{array}{l}\text { Ohio Calibrated } \\
\text { Enflurane } \\
n=168\end{array}$ & $\begin{array}{l}\text { Ohmeda Isotec 4 } \\
\text { Isoflurane } \\
n=187\end{array}$ & $\begin{array}{l}\text { Dräger Vapor 19.1 } \\
\text { Isoflurane } \\
n=180\end{array}$ \\
\hline $\begin{array}{llll}\text { Carrier flow } \\
\text { Rate }\end{array}$ & $\begin{array}{l}\mathrm{t}=7.28 \\
\text { Pelium }\end{array}$ & $\begin{array}{l}\mathrm{t}=-1.89 \\
P=0.0001^{*}\end{array}$ & $\begin{array}{l}\mathrm{t}=-12.67 \\
P<0.0001^{*}\end{array}$ & $\begin{array}{l}\mathrm{t}=-2.34 \\
P=0.020\end{array}$ \\
Concentration & $\mathrm{t}=-5.93$ & $\mathrm{t}=-4.57$ & $\mathrm{t}=-3.46$ & $\mathrm{t}=7.39$ \\
Dial setting & $P<0.0001^{*}$ & $P<0.0001^{*}$ & $P=0.0007^{*}$ & $P<0.0001^{*}$ \\
& $\mathrm{t}=4.55$ & $\mathrm{t}=-4.27$ & $\mathrm{t}=-2.09$ & $\mathrm{t}=-2.61$ \\
& $P<0.0001^{*}$ & $P<0.0001^{*}$ & $P=0.038$ & $P=0.010$ \\
\hline
\end{tabular}

$* P<0.01$.

from four vaporizer models: the Ohio Calibrated Enflurane, Ohio Calibrated Isoflurane, Ohmeda Isotec 4, and Dräger Vapor 19.1 for isoflurane. Three vaporizers of each model were tested. Helium and oxygen were metered through a standard anaesthesia machine, either an Ohio Modulus I, Ohmeda Modulus II, or North American Drager Narkomed depending on the vaporizer being tested. Gas flow rates were measured with the anaesthesia machine flowmeters. Helium was dispensed through the air channel; the air flowmeter was calibrated for helium by using an oxygen analyzer to balance helium and oxygen flows.

Prior to each experiment, the vaporizer was drained, flushed dry with oxygen, and refilled with fresh liquid anaesthetic to eliminate dissolved nitrous oxide. Anaesthetic vapour concentration and oxygen concentration were measured at the fresh gas outlet with a Datex model 254 Airway Gas Monitor which was calibrated, according to the manufacturer's specification, prior to each experiment. Helium concentration was calculated as 100 minus measured oxygen concentration.

The respective helium concentrations and carrier-gas flow rates studied were $0,30,50$, and $70 \%$, and $0.5,3,6$, and $12 \mathrm{~L} \cdot \mathrm{min}^{-1}$. The vaporizer dial settings were $1,2,3$, and $4 \%$ for isoflurane vaporizers and $1,3,5$, and $7 \%$ for enflurane vaporizers. Measurements were made when the vaporizer output was stable for $30 \mathrm{sec}$.

Some cells in the factorial design were left empty. The Ohio Calibrated vaporizers were not studied under conditions of $0 \%$ or $30 \%$ helium concentration at a flow rate of $12 \mathrm{~L} \cdot \mathrm{min}^{-1}$ because they were mounted on Modulus I anaesthesia machines with a maximum oxygen flow of $6 \mathrm{~L} \cdot \mathrm{min}^{-1}$. Similarly, the Dräger Vapor 19.1 vaporizers were not tested under conditions of $0 \%$ helium at 12 $\mathrm{L} \cdot \mathrm{min}^{-1}$ since the Narkomed anaesthesia machine on which they were mounted was unable to deliver oxygen at $12 \mathrm{~L} \cdot \mathrm{min}^{-1}$.

The anaesthetic concentration at the fresh gas outlet, measured in volumes $\%$, was converted to $\%$ deviation from baseline; baseline was defined as the concentration at a flow rate of $3 \mathrm{~L} \cdot \mathrm{min}^{-1}$ and a helium concentration of zero for each vaporizer dial setting. This allowed comparison of vaporizer outputs at different vaporizer dial settings. Multiple linear regression (stepwise regression, backward elimination) was used to investigate separately the effects of helium concentration, carrier-gas flow rate, and dial setting on output concentration for each vaporizer. The analysis was performed using ABstat, version 6.03 (Anderson-Bell Corp., Parker, CO). A probability < 0.01 was accepted as significant.

\section{Results}

The results of the multiple linear regression analysis are summarized in the Table.

The output of the Ohio Calibrated Isoflurane vaporizer was decreased by decreases in carrier-gas flow rate, decreases in helium concentration, and increases in dial setting. The Ohio Calibrated Enflurane vaporizer had a decreased output with increases in helium concentration and dial setting. None of these changes was clinically important since output varied by less than $\pm 5 \%$ of baseline under all conditions (Figure).

Carrier-gas flow rate and helium concentration influenced the output of the Ohmeda Isotec 4 (Table). Overall, vapour output from the Isotec 4 decreased with increases in flow rate and increases in helium concentration. There was also an interaction between carrier-gas flow rate and helium concentration: output increased with increases in helium concentration at 0.5 and $3 \mathrm{~L} \cdot \mathrm{min}^{-1}$, but decreased with increases in helium concentration at 6 and 12 $\mathrm{L} \cdot \mathrm{min}^{-1}$. This effect was only clinically important at flow rates of $12 \mathrm{~L} \cdot \mathrm{min}^{-1}$ where concentrations of $70 \%$ helium resulted in a $17 \%$ reduction in output from baseline (Figure).

The anaesthetic output of the Dräger Vapor 19.1 was only influenced by helium concentration (Table). Increas- 


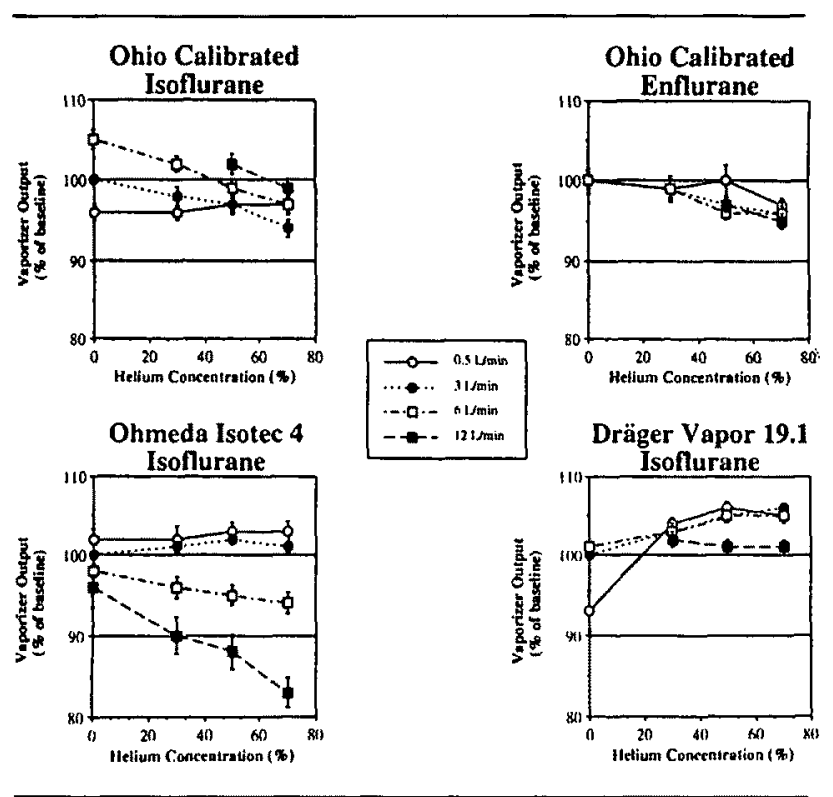

FIGURE Output from four vaporizer models as a function of helium concentration in the carrier gas. Values are means \pm SEM from three vaporizers at four dial settings. Values are expressed as \% of baseline, which is the vaporizer's output at a carrier-gas flow rate of $3 \mathrm{~L} \cdot \mathrm{min}^{-1}$ and a helium concentration of zero, for each dial setting.

ing the helium concentration caused a clinically unimportant increase in the vaporizer output (Figure).

\section{Discussion}

Helium has been advocated for use in laser surgery and for patients with respiratory obstruction. Its high thermal conductivity decreases the risk of endotracheal tube ignition by carbon dioxide laser light. ${ }^{3}$ When turbulent flow exists, such as during respiratory obstruction, its low density improves pulmonary ventilation. ${ }^{4,5}$

It is important to know whether helium affects vaporizer output because vapour concentration cannot be monitored with clinical mass spectrometers if helium is used. Helium interferes with mass spectrometers and causes an artificial increase in the measured concentration of all gases, including volatile anaesthetics. ${ }^{8}$ Therefore, respiratory gas monitoring may not be possible, unless alternative analyzers (e.g., infrared or raman spectroscopy) are available.

This is not the first study of the influence of helium on vaporizer output. However, previous studies were done on vaporizers which are no longer being manufactured. Helium decreased the output of the Cyprane Fluotec Mark II, the first common concentration-calibrated vaporizer. ${ }^{6,9}$ It did not cause a clinically important change in the output of the Dräger Vapor or Cyprane $\mathrm{Tec} 3$, predecessors of the Dräger Vapor 19.1 and Ohmeda Isotec 4, respectively. ${ }^{1}$ One of the vaporizers that we studied, the Ohio Calibrated Enflurane vaporizer has been previously studied. ${ }^{6}$ Helium did not affect its output except at high dial settings.
The carrier-gas flow rate and vaporizer dial setting could modulate any effect of helium on vaporizer output. Calibrated vaporizers split the carrier-gas flow into two streams. One is diverted into the vaporizer chamber and the other into the bypass channel. The proportion of gas going into each stream, and thus the vaporizer output concentration, depends on the resistance through each channel. Resistance is a function of gas viscosity during laminar flow and gas density during turbulent flow. Whether flow is turbulent or laminar depends in part on the ratio of flow rate to channel diameter and these are affected by carrier-gas flow rate and vaporizer dial setting, respectively.

We studied the effect of helium on the output of four modern vaporizers over a range of flow rates and dial settings. Fresh anaesthetic liquid was used to prevent artifact due to dissolved nitrous oxide coming out of solution. We did not measure the temperature of the anaesthetic liquid, which could affect the vaporizer output as it cools during vaporization. However, the order of flow rates was randomized so that any temperature effect would be distributed over all of the measurements.

We conclude that helium causes statistically significant but clinically negligible effects. The output decreases in the Ohio Calibrated and Ohmeda Tec 4 vaporizers and increases in the Dräger Vapor 19.1 vaporizers. The changes are within $\pm 10 \%$ of baseline, except in the Isotec 4 which had a $17 \%$ decrease in output at high flow rates and high helium concentrations. This variability is within the specified accuracy of each vaporizer ${ }^{10}$ and is comparable to the variability in output which occurs due to carrier-gas flow rate, dial setting, and temperature. These four vaporizers can be used safely with helium.

\section{References}

1 Palayiwa E, Sanderson MH, Hahn CEW. Effects of carrier gas composition on the output of six anaesthetic vaporizers. Br J Anaesth 1983; 55: 1025-36.

2 Gould DB, Lampert BA, MacKrell TN. Effect of nitrous oxide solubility on vaporizer aberrance. Anesth Analg 1982; 61: 938-40.

3 Pashayan AG, Gravenstein JS. Helium retards endotracheal tube fires from carbon dioxide lasers. Anesthesiology $1985 ; 62: 274-7$.

4 Lu T-S, Ohmura A, Wong KC, Hodges MR. Helium/oxygen in treatment of upper airway obstruction. Anesthesiology $1976 ; 45: 678-80$.

5 Rudow M, Hill AB, Thompson NW, Finch JS. Heliumoxygen mixtures in airway obstruction due to thyroid carcinoma. Can Anaesth Soc J 1986; 33: 498-501.

6 Prins L, Strupat J, Clement J, Knill RL. An evaluation of gas density dependence of anaesthetic vaporizers. Can Anaesth Soc J 1980; 27: 106-9. 
7 Pedhazur EJ. Multiple Regression in Behavioral Research: Explanation and Prediction. 2nd ed. New York: Holt, Rinehart, and Winston, 1982: 334-7.

8 Siegel $M$, Gravenstein $N$. Evaluation of helium interference with mass spectrometry. Anesth Analg 1988; 67: 887-9.

9 Stoelting $R K$. The effect of nitrous oxide on halothane output from Fluotec Mark 2 vaporizers. Anesthesiology $1971 ; 35: 215-8$.

10 Dorsch JA, Dorsch SE. Understanding Anesthesia Equipment: Construction, Care and Complications. 2 nd ed.

Baltimore: Williams \& Wilkins, 1984. 92-118. 